\title{
REVIEW
}

\section{THE DEVELOPMENT OF DIGITAL ECONOMY IN INDONESIA}

\author{
Ahmad Zafrullah Tayibnapis, Lucia E. Wuryaningsih, Radita Gora
}

At the beginning of the journal, the authors provide information that internet users in Indonesia have reached more than $50 \%$ of the total population in Indonesia. The development of e-commerce in Indonesia reached valuation up to US\$87.8 or 52\% from e-commerce market in South-East Asian. Nowadays society prefers anything practical and inexpensive rather than doing it in a traditional way. That's why this lifestyle changes in digital society are serious threats to conventional businesses which haven't changed their business style to meet with people expectation. The results from this study indicate that there are still various problems in regulation, collaboration, and infrastructure. This problems need to be resolve so that it won't interfere with the growth of digital economic and financial system in Indonesia.

The first part of this journal explained that there is a rapid development of technology-based financial services in the era of industrial revolution 4.0 in Indonesia. Developments in fintech and digital banks show that technology plays an important role in providing enhanced financial services which provides convenience to customers and helps in saving time. The presence of digital wallets, ATMs, credit cards, internet banking, smartphone's financial applications, and other digital financial tools can be a new opportunity to create efficiency and effectiveness for society in conducting financial transactions. However, the development of the digital economy also brings threats to society such as digital-based fraud.

UK, Japan, and Singapore are able to prove that the financial technology brings beneficial impact to their banking institutions, such as lower operating cost and raise low-cost funds from customers. In this digital economy era, it is necessary for Indonesia to also use the technology-based financial system in order to maintain a stable and strong financial sector so that Indonesia's future economic growth will be at $6 \%$ per annum. This means that banks, insurance, capital markets, and startup companies should be boost in order for Indonesian financial sector could grow five times its current position.

The third section of 'Literature Review' journal elaborates that the financial system of Indonesian Economic plays a huge role in providing financial service facilities, which divided into depository financial institution and non-depository financial institution. It is 
important for the financial system to maintain stability and minimize the chance of economic crisis. A stable financial system capable of allocating financial resources and avoid arising problems in real sector activities, also remains capable of performing intermediary functions. Several theories by experts support the existence of financial technology which is the result of the development of Indonesia's digital economy. The rapidly growing financial technology in form of e-business in Indonesia produces new products and services that can be held by each party under various categories, such as payment system, market supporters, investment management and risk management, and other financial services.

Authors refer this research is conducted qualitatively because the main purpose of this research is to comprehend digital economic phenomenon from internet users. Primary data which is used in this study are from 100 respondent and secondary data are from various reliable references.

The conclusion is that digital technology has an important role in providing more efficient and effective banking / non-banking product and services which the society appreciates. The digital-based economy will increase as well as the economic growth and per capita income in Indonesia. However, the developments of digital banking and financial technology also have negative effects on financial stability. Data and documents are accessible through internet network in which increase the amount of possible fraud. Relationship between devices in accessing the internet could create economic losses. In addition, the existence of online businesses and peer-to-peer loans without collateral could cause insecurity if it isn't done carefully.

\begin{tabular}{lcc}
\multicolumn{1}{l}{ Nama } & NRP & KP \\
Anthony Faustin Setiahadi & 130318080 & G \\
Berlinda Rosaline & 130318103 & G \\
Celine & 130318073 & G \\
Vivian & 130318091 & G \\
Vierry Susanto & 130318024 & G
\end{tabular}

